\title{
Introduction to the Handbook of Organised Crime and Politics
}

\author{
Felia Allum, Stan Gilmour and Catherine Hemmings
}

\section{INTRODUCTION}

A man in his thirties with black hair sits behind a desk. He is a former Camorrista who held an important role in his clan because he was one of the clan's mediators with local politicians. He is unforgiving of politicians: "the ambition of all politicians is to "arrive", without looking anyone in the eye ... honestly or dishonestly, the important thing is to arrive' (interview 1, 1997, p. 3). But then, he explains that politicians were often only manipulated by the Mafiosi in their quest for public contracts and funds:

the tendering process for public contracts is organised by the local council, the decisions are taken by a board of councillors, the mayor and his deputy; all these people took orders from us. We knew from the start which contract we wanted to win and then, we would approach them through important people, influential people in the town. For example, builders or councillors, individuals who could approach certain people. We would manipulate the tendering process in our favour, indeed ... we already knew who would win the contract, we knew who would do what, how much and when. (ibid.)

Is this what the relationship between organised crime and politics looks like across the world? Or, is this relationship a more complex and delicate one? One that cannot be categorised so easily? So, where do we start our analysis? Let us start with organised crime.

Organised crime is not a phenomenon that has been easy to define and it remains an open-ended question and an ongoing debate among academics, practitioners and policymakers as to what organised crime actually is and what its main features are. There exists no major agreement or consensus and therefore it remains a controversial, contentious and contested term, leading to many a headache.

The study of organised crime has expanded, developed and intensified beyond recognition since the early 1980s (Paoli and Fijnaut, 2006). Back then, there were books on Italian mafias in Italian for anyone who cared to read them (Pantaleone, 1972; Arlacchi, 1983; Cantanzaro, 1988), and some on the history of the American La Cosa Nostra and wider organised crime analysis (Chambliss, 1978; Kelly, 1986; Abadinsky, 1981; Block and Chambliss, 1981). The end of the Cold War, greater European Union (EU) integration, accelerated globalisation and a predominant economic laissez-faire ideology changed this scenario drastically: 30 years on, organised crime has become part and parcel of security studies and conflict and security teaching programmes, and just as relevant as terrorism studies. Not quite as popular as terrorism, organised crime now has its place in university degree programmes and this is reflected in the mass production of books, articles, projects and public administration interests.

Structural changes in the international environment pushed organised crime into the spotlight and onto political and research agendas. But organised crime is not a new 


\section{Handbook of organised crime and politics}

phenomenon and has always existed, changing and adapting to new habitats. Post-1990 it became a more mainstream topic. In the early 1990s, a tension appeared in the debate about how organised crime should be dealt with in an international context, and as a security threat. Some argued that its perceived threat was exaggerated and it was used as a pretext for EU political elites to push their new 'internal soft security agenda' (Gachevska, 2009, p. 12) and develop and integrate Eastern European countries; in other words, 'It was re-discovered as a potential common problem for less powerful as well as more powerful states, a "new global challenge", which the world had to urgently address through international cooperation and joint policies' (ibid., 2009, p. 10).

Others, working on national contexts, asked for a reflection about what organised crime looked like in a changing local, national, international and global environment. They argued that it was not just an Italian or American phenomenon, and that perhaps it was time to analyse the latest forms of organised crime as a product of capitalism, which cohabited perfectly in democratic conditions (Allum and Siebert, 2003). This debate was not about exaggeration, but about identifying what organised crime looked like and accepting that it may be a problem for all countries, because it was part of their very foundation.

Even today the majority of studies on organised crime remain, to a large extent, within traditional 'mainstream' criminological and sociological interests. The field is, however, widening as researchers seek greater understanding of the development and emergence of organisational structures (Catino, 2014), investigating the history of groups and structures, analysing the complexity of the different activities (local, national and international), differentiating between their various operational activities, the impact on civil society, the economic systems, the role of globalisation, movement of organisations, the recruitment process, the shift in policy-making approaches, and responses by civil society and law enforcement agencies (Harriot, 2007; Levi, 2014).

Perhaps one of the reasons for the limited number of empirical studies on organised crime is that it is not a straightforward subject to study. Like many criminological phenomena, it is complex for a researcher interested in its internal and external dynamics to study this up front because of its limited access and potential danger (Rawlinson, 2000; Hobbs, 2000).

Another aspect that has also been under-researched is the relationship between these criminal organisations and the political elite, political institutions and politics in general (Hirschfeld, 2015). In other words, the relationship, the interconnection, the overlap, the association, the linkages, the alliance, the bond and the dependencies between criminal organisations and politics. It is this space of contact, the terms of this relationship, the items that are exchanged and the negotiations that take place, that we wish to analyse in this Handbook, for this relationship is not always a violent or adversarial one, but can often be consensual, egalitarian and proactive.

\section{THE FOCUS OF THIS $H A N D B O O K$}

It is upon these varied and complicated relationships that we wish to shine a light by presenting, unpacking and analysing them in this Handbook. The academic 'handbook' has become a very fashionable item on bookshop and library shelves. Indeed, over recent 
years, academic publishers have started to extensively publish such handbooks; often on the most pertinent and important subject matter (for example, terrorism, identity studies, migration and globalisation, immigration and refugee studies).

After much reflection, we felt that even this under-researched and poorly understood 'hidden face' and darker side of organised crime deserved to be analysed and considered. We were interested in unpacking this complex subject for students and researchers alike, rather than ignoring it or leaving it to one side as if it did not exist.

Therefore, this is above all a research-led Handbook, which means that we have given authors maximum flexibility in the way they present their material, ideas and analysis. The intimate relationship between organised crime and politics exists not only in high-profile countries such as Italy; it also exists in many shapes and forms in different countries and regions, and its existence makes us challenge our assumptions, question our values, and reflect upon the nature of capitalism and democracy, and on the workings and functioning of democracy. This Handbook is not about scaremongering, but about stimulating discussions and debates. We do not seek to fuel a moral panic, but make a request to reflect about the meeting point between organised crime and politics, between the upper- and underworlds of our societies, and how they interact and engage.

Not all chapters analyse this relationship in democracies. There is no single model of democracy, but there are commonly accepted democratic principles (respect for human rights, free and fair elections, a free press, the right to form political parties) and values (transparency, accountability, participation) that provide a basis for all democracies (IDEA, 2002, p. 10); this provides another reference point to challenge some long-held beliefs about the nature of organised crime.

This Handbook therefore seeks to analyse the most intangible dimensions of organised crime: the nature of its relationship with the political world and its institutions, where such a relationship exists. It is concerned with the space and meeting point between criminal organisations and politics. This intersection (or integration) can take on very many forms and shapes, according to its geographical context, the historical origins of the criminal organisation and the existing structure of the political institutions. What is possible, however, is an attempt to understand the nature of the relationship and the exchanges within it in order to identify common features and key differences. This is what we seek to do in this volume.

As a result, this Handbook seeks to locate itself within a multidisciplinary discussion to provide an overview of the relationship between criminal organisations and politics, or what Clayton has called 'high-level linkages' (see Cross, 2016). It seeks to provide a fresh look at this complex, forever changing and complicated relationship by presenting new material and thoughts from a variety of political scientists, criminologists, anthropologists, sociologists, and European and international studies experts. It is not in the traditional style of a handbook, in the sense of being a manual, an 'ABC', a directory or an almanac that produces and provides clear, objective and systematic facts and information about the relationship between organised crime and politics. It cannot do this, because of the subjective, imperceptible and volatile nature of the subject matter.

The two main aims we set for this Handbook are:

1. To shine a light on an under-researched question and give a coherent and multidisciplinary overview using the available material of the current relationships between 


\section{Handbook of organised crime and politics}

criminal organisations and politics, in countries and organisations where research is possible and is being undertaken. In other words, to provide a new and systematic picture and analysis of what the relationship between criminal organisations and politics looks like in different national contexts.

2. To raise questions and be thought-provoking about the nature of the relationship between criminal organisations and politics, and in this way to stimulate a debate about how democracy, political systems, civil society and economic systems can be improved in order to counter the possible infiltration of these organisations, their associates and representatives.

This Handbook addresses and tackles a variety of important debates around these aims, and we would recommend readers to enter these debates and ask questions such as:

1. Is organised crime political? Can it be political at any point in time? What does this look like? Mafias are political by nature, but does this mean that organised crime groups have to be? How does organised crime engage with politics? Do extra-legal governance structures hold legitimacy?

2. What, if anything, is significant about the presence of organised crime groups in modern democracies? It had been argued that modernisation would wipe out and eliminate organised crime, but this has not happened. If anything, organised crime groups have flourished in democratic and capitalist conditions. Why does this happen? What does this say about the quality of democracy and capitalism?

3. Who inhabits the 'grey area' of accomplices, enablers, facilitators and helpers? Why and how does this activity take place? Why does this complicity exist?

4. What is the role of capitalism as a driver for this relationship?

5. What can be said about the movement and migration of transnational organised crime groups? Can non-native groups ever have a relationship with politics outside their territory or origin?

6. Where should we focus the fight against the relationship between organised crime and politics? How do countries counter corruption locally, nationally and internationally?

We hope that the reader will begin to see that organised crime, however unsophisticated and random, cannot be analysed without including politics as a point of reference.

\section{Organised Crime or Mafias?}

Before considering different research methods and their application to the study of organised crime and its relationship with politics, it is necessary to address the first challenge: that of trying to define some of the features of organised crime itself. The many and various attempts to construct a universal definition suggest an inadequacy of common language to capture and convey both the intrinsic nature and the explicit characteristics of the phenomenon.

Rather than rehearse the extensive academic and practitioner definitions and debates regarding the validity or otherwise of these definitions, one just has to look at the number of definitions on Klaus von Lampe's website. ${ }^{1}$ The following descriptions aim to provide sufficient understanding of what is meant by 'organised crime' for the purposes of 
considering the risks, challenges and opportunities facing the researcher, starting with the United Kingdom (UK).

The UK Government's Serious and Organised Crime (SOC) Strategy, presented to Parliament in October 2013, makes reference to the lack of a legal definition of organised crime in England and Wales but goes on to describe it as:

$2.5 \ldots$ serious crime planned, coordinated and conducted by people working together on a continuing basis. Their motivation is often, but not always, financial gain.

2.6 Organised Crime is characterised by violence or the threat of violence and by the use of bribery and corruption: organised criminals very often depend on the assistance of corrupt, complicit or negligent professionals, notably lawyers, accountants and bankers. Organised crime also uses sophisticated technology to conduct operations, maintain security and evade justice. (HM Government, 2013, p. 14)

The Organised Crime Group Mapping programme (Levi, 2014, p. 10), undertaken across law enforcement agencies in the UK, mirrored many of the characteristics included in the United Nations (UN) Convention against Transnational Organized Crime (UN, 2000) and the UK's SOC strategy descriptions, such as an assessment of the capacity and capability to commit serious crime on a continuing basis, including elements of planning, control, structure and group decision-making. In this context, 'serious crime' is defined in accordance with section 93(4) of the Police Act 1997 as crime that involves the use of violence, results in substantial financial gain or is conducted by a large number of persons in pursuit of common purpose, or crime for which a person aged 21 or over could expect to receive three or more years' imprisonment on first conviction.

The inclusion of sentencing outcomes in the above descriptions is interesting insofar as it puts an emphasis on the crime classifications, criminal justice outcomes and, in the UK, Crown Prosecution Service charging decisions. The extent to which this captures the wider harms caused by organised crime beyond the prosecution of individual crimes is debateable. The working definition by law enforcement in the UK is sufficiently ambiguous in the use of 'could expect to receive' to be dependent on sentencing guidelines and practice in each criminal justice area.

The UN Convention against Transnational Organized Crime (UN, 2000) defines an organised crime group as:

A structured group of three or more persons, existing for a period of time and acting in concert with the aim of committing one or more serious crimes or offences established in accordance with this Convention, in order to obtain, directly or indirectly, a financial or other material benefit. (Article 2)

In this instance, a 'serious crime' is an offence punishable by a maximum imprisonment of at least four years or a more serious penalty. A 'structured group' is defined as a group not randomly formed for the immediate commission of an offence, but does not necessarily have defined roles, continuity of membership or a developed structure.

By way of comparison, the United States Federal Bureau of Investigation (FBI) website $^{2}$ defines transnational organised crime as 'Those self-perpetuating associations of individuals who operate transnationally for the purpose of obtaining power, influence, and monetary and/or commercial gains, wholly or in part by illegal means'. Varese, when considering Italian organised crime, draws the distinction between crime that is organised, 


\section{Handbook of organised crime and politics}

and the phenomenon that is organised crime. Whilst the former seeks to perpetuate criminal offences in a pre-planned way, the latter "seeks "to govern" the underworld ... . [and] aspires to obtain a monopoly over the production and distribution of a certain commodity in the underworld' (2001, pp.4-5).

Increasingly, organised criminals are diversifying their criminal and commercially viable activities in response to changing crime landscapes and technological developments. As such, the sense of control is increasingly likely to extend beyond single commodities, and could lead to global relationships between criminal groups for mutually beneficial outcomes.

Hagan (2006, p. 134) introduced a helpful distinction between 'Organised Crime' (capitalised) to refer to criminal organisations and 'organised crime' (lower case) to refer to criminal activities that require a degree of organisation. It might therefore be useful to define organised crime and criminal organisations in relation to mafias, as this may allow us to conceptualise their main differences and thus to gain a better understanding of what they both are.

The terms 'organised crime' or criminal organisations and 'mafia' are often used interchangeably, in the same way as the word 'mafia' has become a catch-all term used to denote all Italian criminal groups regardless of subtle differences, when there are clear regional differences between Sicilian Cosa Nostra, the Calabrian 'Ndrangheta, the Neapolitan Camorra and the Pugliese Sacra Corona Unita. Organised crime and mafia are not the same thing. Both terms have evolved over time, according to national and international political contexts, agendas and climates: they 'have shifts in meaning, territorial scope' (Paoli and Vander Beken, 2014, p. 26).

Two useful ways of conceptualising the differences between organised crime and mafias are: (1) to see organised crime as an overarching genus with many species, including mafias and gangs; (2) to see criminal behaviour as being on a spectrum, from gang behaviour to mafia behaviour. In the first framework, organised crime is a general form of criminal behaviour and organisation, while mafias are a specific form of that general behaviour. A bit like a general genus of cats and individual species such as cheetahs, lions, jaguars. Organised crime has general characteristics as a genus, while there exist different species such as gangs, criminal enterprises and mafias. One of the specific characteristics of a mafia is that it is interested in political power and has certain political aspirations, because it is territorial and ultimately seeks political power in order to control this local territory and all that takes place there, which is not the case with the other species. This is slightly different from Varese (2010), who argues that 'OC [organised crime] and Mafia belong to the same genus of states and insurgencies' (ibid., p. 14) and they are both forms of governance: 'mafias attempt to supply protection' (ibid., p. 17) while OC 'attempts to regulate and control the production and distribution of a given commodity or service unlawfully' (ibid., p. 14).

The second framework sees criminal behaviour on a continuous spectrum, with gangs at one end and mafias at the other. Armao argues that:

we may imagine a sort of continuum, starting from organised crime in the sense of a group of individuals who act together to commit crimes of different types (such as robberies, drug-pushing, etc.), even on a transnational basis; the moving on to crime syndicates as wellstructured criminal groups with different hierarchical roles devoted to the search for profits, acting first of all as entrepreneurs; and finally at the other end of the continuum mafia, as the 
most specialised criminal group, also using politics (i.e. the control of a territory) to obtain profits. (Armao, 2003, p. 28)

Therefore, at one end, there is simple and unsophisticated criminal behaviour and organisation, in other words, individuals come together as groups without much in the way of internal organisational structure or rules, and undertake predatory crimes. The more you move towards the right of the spectrum, the more the organisational structures and crimes become rational and thought-through, even being able to challenge the structures of the state (Harding, 2007). Gangs are units that undertake crime; mafias are extra-legal governance structures that challenge the state's power and structures because they seek political power in order to access money, in particular, state funds. In this framework mafias can also begin to look like terrorist groups, challenging state legitimacy as well as their legislation.

Sciarrone and Storti (2014, pp. 5-6) add to this definition by elaborating an ideal 'mafia type' in the following terms:

- The individuals belonging to mafia type criminal organizations make up a secret society, with specific bonds of loyalty and a well-defined hierarchy of control, and act in pursuit of gain, reputation and security;

- The major means used by the mafia consist of exercising violence, whether actual or threatened, in instrumentalising specific, traditional, cultural codes and manipulating social relationships in order to ensure the cooperation of other actors outside the organization and, in particular, to establish mutual exchanges in political and economic circles. Thus, what distinguishes mafiosi is their pronounced capacity for accumulating and employing social capital;

- The mafia's organizational structure is that of a network organization, with a certain degree of internal cohesion and an appreciable level of openness to the outside. Specifically, mafiosi are bound to each other by strong ties, and with outside social groups by weak ties. In addition, the organizational relationships between the network's members may be closer in some cases, looser in others, thus enabling parts of the organization to have more independence;

- The mafia's organizational form includes two dimensions that are combined with each other in a variety of ways: 1) that of an "organization for illicit trafficking", which makes it an "enterprise" that operates between the legal and illegal markets; and 2) that of an "organization for control of the territory" of the local societies in which it is embedded. This dimension is cultivated by using the resources of violence and social capital discussed above, whereby the mafia can exercise protection extortion.

Abadinsky's (2012, p.17) solution to this definitional problem was to adopt eight major and general characteristics which he used to differentiate between petty crime and organised crime. Organised crime did not have to have all these features but these features clearly gave a standard of what organised crime looked like. So for him, organised crime:

1. has no political goals;

2. is hierarchical;

3. has a limited or exclusive membership;

4. constitutes a unique subculture;

5. perpetuates itself;

6. exhibits willingness to use illegal violence;

7. is monopolistic; and

8. is governed by explicit rules and regulations. 


\section{Handbook of organised crime and politics}

Organised crime groups are only interested in profit and they will do whatever is necessary to attain this. If this includes having to deal with politicians (from any political party) then, so be it. Moreover, having no political goals or allegiance is a distinctive feature in deciding whether the activities are about the furtherance of crime or part of a terrorism campaign. Put simply, organised crime is a challenge to the legitimacy of a state's laws, and terrorism is a challenge to the legitimacy of the state itself. Whereas organised crime can usurp systems of governance, its goal is to carry out its activities unhindered, not to establish a new political order. There is sometimes a fine line to be drawn, and many of the chapters in this volume outline examples of rampant extra-legal governance (for example, Mexico) or state capture (for example, Western Balkans).

\section{Defining Politics}

What do we mean by 'politics', and organised crime's relationship with politics? The term 'politics' has a multitude of meanings, and organised crime's relationship with politics is never the same. In its broadest sense, we agree with Leftwich when he argues that 'politics is at the heart of all collective social activity, formal and informal, public and private, in all human groups, institutions and societies' (quoted in Heywood, 2004, p. 59). More precisely, 'wherever we live and work in groups, we are always engaged in activities of conflict, negotiation or co-operation in the use, production or distribution of resources and that relations of power are always central to them. That is, we constantly engage in politics' (Leftwich, 2004, p. 112).

In this volume, we have adopted a very broad and flexible understanding of what politics is and how it engages with organised crime. We have adopted Heywood's general overview of what politics is in order to allow authors to present their research findings and reflections without being constrained by one specific narrow definition of politics.

Therefore, we are defining politics both in a narrow and a broad sense. Politics is both an arena, that is, a location and a space in which behaviour becomes 'political because of where it takes place' (Heywood, 2013, p. 3); and a process, that is, a mechanism, rules and regulations which is 'political behaviour' because it 'is behaviour that exhibits distinctive characteristics or qualities and so can take place in any and perhaps all, social contexts' (ibid., 2013, p. 3).

Within this, we have two general approaches and four specific sub-approaches and understandings of what politics is. The first general approach sees politics as an arena, a physical space, which can be understood as being: (1) the art of government and affairs of the state; in other words, the specific workings and machinery of government (cabinets, legislative chambers, government departments) with specific individuals involved (politicians, civil servants, lobbyists); or (2) public affairs; this meaning goes beyond the narrow idea of the workings of political institutions to the more general notion of 'public life' and civil society. In other words, politics is also about contributing to a public, collective life in order to create a just society.

From this, the dichotomy of public versus private sphere emerges. This can have different interpretations: one which sees the public being the state, and the private being civil society; and the other which sees the public sphere being all that is involved in civil society (all the non-state and non-economic actors, such as the Church, the media, voluntary associations), as opposed to the private sphere which is predominantly the family. 
The second general approach is one which defines politics as a process and a way of doing things. Politics can be: (3) a specific way in which decisions are reached in a complex society where there is a wide dispersion of power; in particular, through negotiations, compromises and consensus (this can also include elections, campaigning, and so on). It can also be understood as: (4) in essence, being power. In other words, 'politics can be seen as a struggle over scarce resources, and power can be seen as the means through which this struggle is conducted' (ibid., 2013, p. 10). In this volume, all these different forms of politics are discussed and analysed. But, how do criminal groups engage with politics? Is it only through political corruption or in other ways?

\section{Defining Political Corruption}

According to the definition of political corruption provided by the International Monetary Fund (IMF, 2007) political corruption is distinct from organised crime and concerns a specific abuse of power through 'the misuse by government or political officials of their governmental powers and resources for illegitimate, usually secret, private gain'. Or in the words of Della Porta and Vannucci (2017, p. 16), political 'corruption refers to the abuse of public resources for private gain, through a hidden transaction that involved the violation of some standards of behaviour'. Unrestrained political corruption is known as 'kleptocracy'; meaning the 'rule by thieves'; the term strongly aligns with a sense of illegal gain or illicitly obtaining something from another. ${ }^{3}$

Organised crime and political corruption are therefore not the same thing even if they produce the same negative effects on civil society. Indeed, political corruption can undermine, fracture or, at worst, dissolve the social and political contract that binds public officials to the public they serve. Whether democratic, republican, monarchical or dictatorial, the relationship between state actors and citizens relies on trust (real or assumed); as with most relationships, the denigration of trust will cause tension and negative consequences. When considering political corruption, the extent of these consequences will be dependent on the scale of the corruption. If it concerns only a few, isolated individuals, it may be possible to expel them with minimal impact on public confidence or state reputation; more widespread political corruption can lead to abusive practices that damage the state's citizens and economic stability, and could inhibit cultural and societal development.

Poor governance in public administration or ineffective control frameworks, increase the opportunity for public officials to engage in corrupt practice. Empirical evidence also indicates that less democratic political structures lend themselves to more widespread corrupt practice. Whilst political corruption may bring the official into contact with organised crime or enable the furtherance of organised criminal activity, the official continues to be a direct beneficiary of their actions, which is their primary motivation.

Returning to a general understanding of organised crime and its relationship with politics, and taking account of the various definitions and categories detailed above, it is perhaps best to consider the modern international or transnational phenomenon of organised crime as an amorphous, evolving, opportunistic way of being, that is characterised by financial gain, power, control, corruption and entrepreneurial drive. It is frequently responsive to external factors, and enabled by political, economic, social, technological, environmental and legal developments. This Handbook seeks to provide examples and analysis of this from around the world. 


\section{Observations on Researching Organised Crime and Politics}

Organised crime has many facets, extending its power and control through profit and exploitation of borders with no consideration of the harm it causes. It was estimated that in 2015, the illicit markets associated with organised crime led to a social and economic cost of $€ 110$ billion in the EU alone, which is roughly equivalent to 1 per cent of EU gross domestic product (Project OCP, 2015, p. $7^{4}$ ). Behind this figure are multitudinous lives and communities blighted by the parasitic nature of organised crime, fracturing normative social structures and undermining egalitarian political frameworks.

An understanding of organised crime in all its forms is necessary to develop our knowledge as well as to enable policy-makers and law enforcement agencies to better protect their citizens, to prevent and detect criminal behaviour, and to diminish the power and scope of these criminal networks. Yet as this Handbook illustrates, the ability to apply common research methods to the study of organised crime and politics is beset by many challenges. Here we reflect upon a few.

There are almost as many classifications of research methods as there are definitions of organised crime; some of which are more plausible for undertaking research in this field than others in terms of obtaining data whilst maintaining the safety and integrity of the researcher. In general terms, according to Dawson, a research methodology is 'the philosophy or general principle which guides the research', whereas the research methods 'are the tools you use to gather your data' (2009, p. 23).

Broadly speaking, research is divided into two main methods - qualitative and quantitative methods - and the researcher faces a decision early on as to which is the most appropriate to a given project, or more commonly the adoption of a mixed methods approach that combines the two. Maruyama and Ryan (2014, p. 366) explain qualitative research thus: 'participants relate stories about their lives that enable researchers to generate hypotheses and themes and, more generally, to understand participants' social worlds from their perspectives'. Further, Dawson (2009, p. 15) expounds that quantitative research 'generates statistics through the use of large-scale survey research, using methods such as questionnaires or structured interviews'.

Whilst the deliberate effort is made to gather information relevant to the task, the supposition that it will be both reliable and unbiased is open to question. For example, when considering police data, the quantitative information retrieved from systems is unlikely to be absolute; it will be subject to human error on the part of the officer or staff member obtaining and inputting the data in the first instance, and may reflect bouts of proactivity undertaken in thematic or geographic areas rather than a holistic overview. The hidden nature of organised crime and corruption further add to the likelihood that quantitative datasets do not reflect the true extent of criminality, criminal networks or criminal capability.

Conversely, qualitative research methods endeavour to explore experiences, attitudes and behaviours beyond numerical or statistical data. A qualitative study requires participants, or access to information previously provided by participants; in the case of organised crime these can be victims and witnesses as much as perpetrators. It can also extend out to include previously undertaken academic research, police and probation interviews, court transcripts and proceedings, memoirs or dramatisations based on true events. 
Sample sizes tend to be smaller in qualitative studies as the focus is on obtaining a depth of information, perhaps centred on a single premise, event or set of circumstances. Difficulties with access to first-hand testimony on organised crime is likely to further inhibit the sample size, which also has the consequence of reducing the likelihood of being able to corroborate or parallel-source the information obtained.

Regardless of the research method adopted, when considering the process of translating research into cogent conclusions there are two primary methods for achieving logical outcomes. Deductive reasoning is a reactive method applied once research has been undertaken and information obtained. Walliman (2011, p. 18) neatly summarises the process in that it 'begins with general statements [...] and, through logical argument, comes to a specific conclusion'. The extent to which the original statements can be tested depends on the availability of sources of data or information that can be gathered and analysed. One of the notable weaknesses with deductive reasoning is that logical conclusions can be drawn from false or untrue statements. Thus, whilst the conclusion may be logically correct, it is essentially invalid.

Unlike deductive reasoning, induction or inductive reasoning is not wholly dependent on the initial statement to draw a conclusion. Commonly, as noted by Blackburn (2016, p. 243), 'the conclusion involves the same properties or relations as the premises', but it is not entirely constrained to them, and enables something beyond the content of the premise to be inferred. Whilst deduction starts with a theory or hypothesis, and seeks to test it through research, induction starts with multiple data and information sets from which it aims to derive patterns and theories in order to arrive at a generalised conclusion.

Turning theoretical methodologies for undertaking research into tangible outcomes requires practical activity. Davies and Hughes (2014, pp.26-33) have drawn up and categorised "fourteen ways of "doing research" to help the researcher consider a range of activities that could be applied to a given question:

1. Interview people using closed questions.

2. Structured written questions, for example questionnaire by mail.

3. Structured written questions by email.

4. Semi-structured reflective interviews.

5. Group interviews.

6. Observe people in action.

7. Analyse written or spoken word.

8. Test a hypothesis.

9. Randomised control trial.

10. Quasi-experimental.

11. Secondary analysis of data.

12. Action research.

13. Case study.

14. Triangulated approach (multiple methods).

Each practical approach can be adopted in isolation or can be used in combination, tailored to suit the specific research question and to maximise the likelihood of achieving the outcomes that will move the research forward. 


\section{Handbook of organised crime and politics}

The first practical challenge facing the researcher who seeks to analyse the relationship between organised crime and politics is access to information or data to conduct independent research (see Sanchez, Chapter 24 in this Handbook, for a very practical example of this difficulty). The research question will inform the type of data necessary to progress to an informed and developed conclusion, but regardless of whether it is quantitative or qualitative, primary or secondary, there are likely to be difficulties with generating, accessing or obtaining sufficient information to satisfy the researchers' needs.

High-profile media coverage of data-leaks, accidental disclosure of private and personal information, concerns around corruption and a recognition that private information has become a lucrative commodity, have all led to public bodies increasingly focusing on data security and information asset ownership. In one regard, this is a positive development intended to give the citizen increased confidence that authorities are managing information appropriately and with due consideration to the risks of breaches in security; however, from the perspective of academic research the fortification of data and information has made it increasingly inaccessible.

With regard to the application of research methods that require direct contact, either oral or written, with perpetrators, victims or witnesses of organised crime, Hobbs and Antonopoulos (2014, p.96) suggest that 'there are seldom any obvious benefits for participants'. In simple terms, organised criminals who are still actively offending are unlikely to respond to requests that will draw attention to themselves or their activities, whilst those who are either imprisoned or no longer actively offending will not wish to incite potential retaliation or be regarded as informants. Victims and witnesses are highly likely to have suffered a degree of psychological or physical harm, and revisiting events may cause post-traumatic stress responses and further harm.

The researcher should also be conscious of the plethora of ethical considerations when instigating a transactional relationship with criminals, especially those who are still actively offending. Any study should give serious consideration to how to manage situations wherein the researcher becomes aware of or inadvertently exposed to live-time offending. This should extend to developing an understanding of when interaction becomes complicity, intervention, or creates an agent-provocateur situation.

Consideration of the statutory requirements of law enforcement when engaging covert human intelligence sources, or covert operations that directly engage criminals in their own environment, may prove a useful prompt or guide to the researcher if considering direct contact methods. This may be particularly relevant for a researcher undertaking ethnographic research methods that require immersion in the community of the groups being studied. Such studies are usually undertaken over several years or more to build up sufficient trust and exposure to gather information; inevitably, this will result in close relationships between the researcher and those in or associated to the crime group, that may blur the lines of professional objectivity.

Incarcerated offenders may be more willing to participate in studies but, in some cases, they may be no less likely to have remained actively involved in organised criminality despite their imprisonment. In these instances, the researcher should remain mindful of the risks that the participant may be disclosing previous or ongoing offending. Also, from the prisoner's perspective, contact with someone outside the prison establishment may be attractive for a variety of reasons. This could lead to the researcher inadvertently being placed in a compromising position, or the subject of the study exaggerating or embellish- 
ing facts, or prolonging the relationship to continue contact with the outside world. The researcher should also consider likely scenarios that may occur when their research subject has concluded their sentence.

Any research methods that involve direct contact with people will necessitate a significant level of pre-planning to identify appropriate individuals, address ethical considerations and secure consent. For those keen to avoid the risks and dangers of studying organised crime through personal interaction with those directly engaged or subject to it, historical or archival research may appeal. Access to data is no less challenging and the need to develop an understanding of the socio-political, economic and legal context becomes central. Archival research does, however, enable a fresh and objective perspective that benefits from hindsight; detachment from the era within which a situation is developing allows reflection and consideration of cause and effect as the outcomes will be known, if not always directly attributable.

Case studies can apply to either contemporary or historical organised criminality. In either instance, dependent on the research question under investigation, it can be difficult to follow a clear thread that attributes the outcomes or manifestation of harm in communities to the activities of a particular crime group. The inability to identify or control all variables within the context of the group subject to the case study (the 'unknown unknowns') and the identification of knowledge gaps with little or no ability to address them (the 'known unknowns') will frustrate researchers as much as law enforcement analysts. It also hinders the attempt to extrapolate conclusions that are more generally applicable, unless multiple case studies are being undertaken in response to a specific question. It should also be noted that attempts to undertake contemporary case studies will be further subject to the challenges of engaging participants as detailed above.

For the researcher undertaking a meta-analysis of existing reports and assessments of organised crime, or attempting comparative research, Hobbs and Antonopoulos (2014, p.98) again offer an insight by highlighting the difficulties inherent in the endeavour, stating that: 'The size of the files, the criteria for selection on behalf of law enforcement, different legal definitions and variations in administrative and legal protocols, and incompatible systems of data management produce such variations that comparative research findings can be rendered virtually meaningless.'

Official data and accounts are often, and understandably, considered the panacea of organised crime information. Law enforcement and governmental agencies are routinely the only sources of primary evidence, but the researcher must remain mindful of the limitations of 'official' data. Quantitative crime data is primarily reliant on victim reporting, with the assumption that organised crime is routinely under-reported as victims are subject to coercive control, intimidated, humiliated or, in the most extreme cases, deceased. The extent of the 'unknown' significantly impacts on the ability to accurately identify trends or common features in the information that is retrieved from systems.

Information frequently results from periods of focused proactivity, rather than being consistently or routinely available and gathered. Information from a police operation will be a combination of primary and secondary data, obtained from sources such as victim statements, witness testimony, intelligence reports, surveillance, communications data and open source information. Each of these is subject to filters of human interpretation or assessment, such as the physical position of the witness, the psychological harm suffered 
by the victim, the data interpretation of the analyst, the meaning ascribed to a visual capture of a meeting by an officer, or the semantics of the inputter. It will also be specific to the geographical location in which it is taking place.

Qualitative data is susceptible to unconscious bias and preconception or prejudice on the part of the researcher, the participant(s) in the study or the third-party data gatherer. Perpetrators, bystanders, victims and researchers each regard a set of circumstances through a unique lens, made opaque by the human ability to justify and adapt to any given circumstance. Critically, an assessment of qualitative information requires the suspension of societal norms or geographically specific normative behaviour in an attempt to understand that which is taking place. The emergence of organised child sexual exploitation, or the recent proliferation of named individuals involved in historic offending is, in part, an example of the inability to acknowledge that such abhorrent behaviour could be present in local communities. The psychological refusal to accept that what is taking place could happen, allows it to continue undetected for protracted periods.

Surveying large groups of people to, for example, canvass societal views on organised crime will be subject to the same ambiguity of definition. The respondent's perspective will also be influenced by their geographic location, recent local and national media reporting, and their lifestyle. To fully understand the responses, the researcher would need to be cognisant of each in order to contextualise the results.

Using an economic analysis can also give a useful and insightful perspective on the scale and methods employed by crime groups. If the planning, commission and benefits of offending are viewed through the lens of simple financial gain, then the corollary rules of supply and demand will provide insight into the relationship between perpetrators, bystanders and victims, as well as the desirability of the commodity (or service) for sale in the particular illegal market. Overlaying economic frameworks and market factors across organised crime networks (or enterprises, in this regard) can also indicate commodity flows that would assist in the identification of intervention opportunities or suggest vulnerabilities being exploited. The application of economic methods enables the attempt to quantify the economic impact of organised crime at micro and macro levels; but, as with all research in this area, it is frustrated by the inaccessibility of reliable data to enable accurate conclusions to be reached.

This brief discussion about research methods, and which methods and approaches potentially to adopt when studying organised crime and its relationship with politics, highlights some of the complications which exist. This makes us realise how precious and valuable the chapters in this volume are. The authors of each chapter explain their methodology, which helps us to gauge exactly what they are focusing on, what material they are using and what they are seeking to explain.

\section{ORGANISATION OF THE HANDBOOK}

There is no doubt that this has been a very arduous volume to put together, as well as taking a long time. This is because of the sensitive nature of the material, its accessibility, but also due to the lack of researchers working in this area (and one of the editors being a full-time police officer!). We pondered about how best to organise the material and decided that the most logical way to organise it was to adopt a geographical rather than 
a thematic approach, as it was not always obvious that similar themes would emerge and talk to each other (even if they did) (see Figure I.1).

Part I of this volume covers Europe and specifically draws on studies of France, Sweden, Germany, Italy, Western Balkans, Ukraine, Bulgaria, post-Soviet Eurasia and Russia. France reveals a presence of organised crime and an absence of mafia. Although the field is under-researched, organised crime appears to act in support of and functions when it aligns with politics. Sweden is characterised by low levels of corruption, with stable political institutions, high levels of political trust and a strong civil society, yet the Syriac Mafia has taken a foothold and its impact is examined. In Germany, there is a lack of research and the dynamics between the political class and civil society are ripe for further analysis, although there is some indication that the 'Ndrangheta is attempting to collude with elements of the upper class. Italy seems to lack a joined-up approach when tackling the problem of mafia infiltration of local councils. With no commonly understood national intelligence picture available to illustrate the scope and scale of the problem, citizens are not able to see the extent of the threat in local or national settings. The Western Balkans see strong links between politics and organised crime, with oligarchs and clans able to dominate and even attempt 'state capture'. Ukraine is characterised as 'frozen conflict', where organised crime is stripping the country's assets.

In Bulgaria, the role of state actors in the emergence of organised crime is explored. The post-Communist transition needed someone to do the 'dirty work', and the political elite turned to organised criminals. In post-Soviet Eurasia, having a Soviet past is a significant predictor of high levels of corruption and the chapter charts the evolution of 1990s street gangs to the capital-based oligarchic structures that dominate as a 'strategic necessity' for some functional responsibilities, for example controlling prisons. Russia is often referred to as a 'Mafia state', but there is some indication that since 2000 there has been a 'state recapture' by the government. The current transitional and 'statist period' is characterised by organised crime as business, with businessmen, politicians and organised criminals benefitting from the 'commercialisation' of government activities and state services.

Part II examines the Americas: the United States of America (USA I and II), Canada, Mexico, Brazil, Guatemala and Colombia. The Mexico chapter is a sociological analysis, highlighting social, economic and political impacts from political 'reciprocity' with organised crime. It maps the 'cartelisation' of the country where narcos attempt to take charge of 'everything', including social norms, yet there is a sense of a distributive ideology in some accounts; this is in contrast to much of the European experience. Brazil sees organised crime taking root in the structure of the state, without 'state capture'. In the transition to democracy, democratic institutions have not been successfully consolidated, leaving space for a relationship to develop between illicit markets and patterns of local insecurity. The production of state money is described as a complex economic - and above all - social operation.

In USA I we see a technical breakdown of organised crime and politics and a warning for the future, where cybercrime gives distance and anonymity, removing the need for 'traditional' mafia skills. USA II examines the moral threat of organised crime and politics and claims behaviour as the more important factor over structure if we are to protect and support the common good. The Canada chapter reviews the Charbonneau Commission into political corruption and outlines the difficulties in investigating corruption, asking: 'Is every inquiry a political exercise?', summarising that 'where there are opportunity 
and potential profits, there will be corruption'. Guatemala reveals a 'state within a state': a joint illegal enterprise whereby a lack of state apparatus allowed state criminal and organised crime to proliferate. The UN Commission Against Impunity is examined in this chapter. In Colombia, politics and crime are intertwined, filling a gap left by a weak state, especially in local areas. Several typologies are examined, as the impact of cartels on political life is unpacked.

Part III covers Africa, and chapters examine Kenya, the Sahel-Sahara region, Sierra Leone, South Africa and Nigeria. The South Africa chapter details the political transition of the country, where a liberation movement, the African National Congress, shifted to a political party in need of funds. It describes how state machinery for enforcement and justice were subverted to protect elements of the political elite, with a reliance on township powerbrokers to maintain local governance arrangements, and organised criminals to mobilise voters. State capture is assessed and some bulwarks that protect the state are outlined. In Nigeria, the symbiosis between organised crime and politics is outlined, with an examination of the scale of theft of natural resources through illicit oil bunkering. The Kenya chapter looks at how corruption and organised crime affect the social fibre of the country, shifting the political arena, strangulating the economy and injuring the criminal justice system. The case studies from the Sahel-Sahara region are used to review elements of state capture against the geopolitical background of the region, and the particular historical trajectories and connectivity between the Mediterranean Basin and North Africa. The Sierra Leone chapter questions the lack of state capture and outlines the roles played by international organisations, the type of corruption that exists, and the democratic political system as bulwarks.

Part IV spans Eurasia, covering Australia, New Zealand, India, China, Malaysia and the Pacific Islands. The China chapter uses English and Chinese language sources to help us understand the relationships between moral values and the law from East and West Hemisphere perspectives. Using the idea of guanxi, or social connections, as a starting point the chapter explores the impact of weakly institutionalised structural protections for private business on the state, and explores four typologies where organised crime flourishes with state protection. The Malaysia chapter picks up the theme of transition, from authoritarian regime into an authoritarian democracy, and attempts to understand the role played by 'secret societies' in relation to the state, asking, 'who is the master, and who is the servant?' The chapter on the Pacific Islands outlines the institutional weakness of law enforcement and oversight agencies and the impact of, amongst other elements, media censorship. The exploitation of natural resources once more forms the backdrop.

The Australia chapter looks into the 'degree of capture' of institutions across seven case studies, and calls for further research to create data that could highlight a range of possible targets for the prevention of organised crime and politics crossovers, as well as further evaluation of impact. The chapter on New Zealand presents a study into patched gangs and questions the received wisdom of law enforcement agencies that could potentially blind them to more pervasive threats. In India, the systemic corruption by consolidated elite interests through the exercise of institutional and criminal influence on the working classes is revealed. A case study is used to illustrate the problems and the difficulties in addressing them as a researcher.

Part V examines the roles played by the EU, the Financial Action Task Force and the UN in combating organised crime and politics. Many of the preceding chapters make reference to these institutions, and this part takes the opportunity to shine a light onto some of the 
clear issues that arise when international agencies attempt to play a role in monitoring, reviewing or rationalising the normative or legislative groundwork in member states.

\section{Emerging Themes}

Each chapter poses several questions about the relationship between organised crime and politics, all in very different settings, with different forms of organised crime and wide varieties of political machinery, but they are still only scratching the surface. One of our objectives was to ask questions and present new and emerging themes for reflection, and some of these themes are reproduced below:

- There is generally a lack of information and data on the problem, especially qualitative data.

- Political transitions create spaces for organised crime to flourish.

- Transitions to democracy against a backdrop of fragmented political systems allow functional alternatives to arise in concert with criminals.

- Strong elites are too often at the centre of corruption.

- Weak states leave space for organised crime to flourish.

- Weak states often rely on organised crime for services.

- There is an observable continuum in politics and crime liaison from street gangs through organised crime to mafias.

- There is an observable continuum from lobbying through nepotism to corruption.

- State capture can be prevented by independent state agencies working with civil society in strong networks.

- State capture and wider problems of organised crime can be prevented by international agencies working in concert with state agencies.

- Mafia states can be undone.

- Secret societies (including secretive state agencies) are often at the centre of problems with organised crime and politics.

- Inter-state relations can provide a bulwark against organised crime impacting upon politics.

- There is a moral threat as well as an existential issue.

- Different forms of corruption exist across levels of political life.

- Where there is an opportunity to make money through political life, there will be corruption.

- Relationships between organised crime and politics need not be stable; they are often unstable, violent, secret, volatile and endlessly renegotiable.

- Natural resources are often the focus of exploitation.

Organised crime and politics are inextricably linked in many countries; many others suffer the effects through weak systems or corrupt leadership; but even strong countries can be beset if they are lackadaisical in their attitude towards organised crime, or if their domestic policies do not meet the need for international cooperation against organised crime. Systematic multidisciplinary research is required to identify the different ways in which forms of organised crime can exert influence on political processes and public institutions, including its moral threat to fair and just systems. This research should generate 
quantitative but most especially qualitative data to assist, inter alia, an understanding of those involved, their methods of organising and operating, their modes of communication, the ways they generate benefits for those involved, the tactics they use to hide their actions and assets, the impact and influence they have from local to global, and the means by which preventive action is best targeted.

There is no doubt that organised crime needs to co-opt politics if it is to survive; and in transitional spaces the opposite is also true. It is also clear that where political administrations are able to make profits, corruption is an ever-present risk. Some of the organised crime groups discussed in this volume carry out their affairs in ways that are more reminiscent of terror groups, and indeed if they were active in some other countries that is probably how they would be treated.

The overarching theme is therefore one of vigilance. If your country is moving towards democratisation, then be sure to promote a consolidated political scene beforehand, otherwise there is a risk that organised crime will insinuate itself in the gaps and usurp the citizen. If your political system allows for monetary exchanges, then be sure that this 'marketplace' (de Waal, 2015) is subservient to the rule of law, otherwise there is a risk that organised crime will monetise the political system and gouge the citizen. If your country does not pay attention to local politics, especially their role in dispute resolution, then organised crime and your citizenry will risk becoming supplicants to unfair practices at one end of the spectrum and (violent) extra-legal governance at the other.

We hope that you read this Handbook with a questioning and critical eye; it is an introduction to a developing area of study and we look forward to seeing further multidisciplinary research adding to it in the future.

\section{NOTES}

1. www.organized-crime.de/organizedcrimedefinitions.htm (accessed April 2018).

2. https://www.fbi.gov/investigate/organized-crime (accessed April 2018).

3. See https://www.fbi.gov/news/stories/us-seeks-to-recover-1-billion-in-largest-kleptocracy-case-to-date for an update on the United States' kleptocracy asset recovery scheme (accessed 31 December 2017).

4. Transcrime, From Illegal Markets to Legitimate Businesses: The Portfolio of Organised Crime in Europe, Final Report of Project OCP Organised Crime Portfolio, https://www.int-comp.org/media/1997/ocp-fullreport.pdf (accessed 20 September 2017).

\section{REFERENCES}

Abadinsky, H., 1981. Organized Crime. Allyn \& Bacon. Boston, MA.

Abadinsky, H., 2012. Organized Crime, 10th edition. Wadsworth. Belmont, CA.

Allum, F. and Siebert, R., (eds), 2003. Organised Crime and the Challenge to Democracy. Routledge. London.

Arlacchi, P., 1983. La mafia imprenditrice: l'etica mafiosa e lo spirito del capitalismo (Vol. 2). Mulino. Bologna.

Armao, F., 2003. Why is organized crime so successful?. In Allum, F. and Siebert, R. (eds), Organized Crime and the Challenge to Democracy, pp. 27-38. Routledge. Abingdon.

Blackburn, S., 2016. The Oxford Dictionary of Philosophy, 3rd edition. Oxford University Press. Oxford.

Block, A. and Chambliss, W.J., 1981. Organizing Crime. Elsevier. New York.

Catanzaro, R., 1988. Il delitto come impresa: storia sociale della mafia (Vol. 9). Liviana editrice. Padova.

Catino, M., 2014. How do mafias organize? Conflict and violence in three mafia organizations. European Journal of Sociology, 55(2), 177-220.

Chambliss, W.J., 1978. On the Take: From Petty Crooks to Presidents. Bloomington. Indiana University Press. 
Cross, J., 2016. 'Gangsters connected - UWI professor claims criminal organisations still linked to political process', Jamaica-Gleaner, 2 December. http://jamaica-gleaner.com/article/lead-stories/20161226/gangstersconnected-uwi-professor-claims-criminal-organisations-still (accessed 1 February 2018).

Davies, M. and Hughes, N., 2014. Doing a Successful Research Project. Palgrave Macmillan. Basingstoke.

Dawson, C., 2009. Introduction to Research Methods: A Practical Guide for Anyone Undertaking a Research Project. How To Books. Begbroke.

Della Porta, D. and Vannucci, A., 2017. Corrupt Exchanges: Actors, Resources, and Mechanisms of Political Corruption. Routledge. Abingdon.

de Waal, A., 2015. The Real Politics of the Horn of Africa. Polity Press. Cambridge.

Gachevska, K., 2009. Building the new Europe: soft security and organised crime in EU enlargement. http://wlv. openrepository.com/wlv/bitstream/2436/77554/1/Gachevska_PhD+thesis.pdf (accessed September 2017).

Hagan, F.E., 2006. 'Organized Crime' and 'organized crime': indeterminate problems of definition. Trends in Organized Crime, 9(4), 127-137.

Harding, C., 2007. Criminal Enterprise. Willan. Cullompton.

Harriot, A., 2007. Organized Crime and Politics in Jamaica: Breaking the Nexus. University of the West Indies Press. Kingston.

Heywood, A., 2004. Political Theory, An Introduction. Palgrave Macmillan. London.

Heywood, A., 2013. What is Politics?, 4th edition. Palgrave Macmillan. London.

Hirschfeld, K., 2015. Gangster States: Organized Crime, Kleptocracy and Political Collapse. Palgrave Macmillan. Basingstoke.

HM Government, 2013. Serious and organised crime strategy. https:/www.gov.uk/government/publications/ serious-organised-crime-strategy (accessed April 2018).

Hobbs, D., 2000. Researching serious crime. In King, R. and Wincup, E. (eds), Doing Research on Crime and Justice, pp. 153-182. Oxford University Press. Oxford.

Hobbs, D. and Antonopoulos, G., 2014. How to research organized crime. In Paoli, L. (ed.), The Oxford Handbook of Organized Crime, pp. 96-117. Oxford University Press. Oxford.

IDEA, 2002.Annual Report.http://www.idea.int/sites/default/files/reference_docs/annual_report_2000-1_screen. pdf (accessed 2 August 2017).

IMF, 2007. Manual on fiscal transparency. Fiscal Affairs Dept., International Monetary Fund. Washington, DC. https://www.imf.org/external/np/pp/2007/eng/101907m.pdf (accessed 31 December 2017).

Kelly, R., 1986. Organised Crime: A Global Perspective. Rowman \& Littlefield. Totowa, NJ.

Leftwich, A., 2004. What is Politics?. Polity Press. Cambridge.

Levi, M., 2014. Thinking about organised crime. RUSI Journal, 159(1), 6-14.

Maruyama, G. and Ryan, C., 2014. Research Methods in Social Relations, 8th edition. Wiley. Chichester.

Pantaleone, M., 1972. Mafia e politica, Vol. 36. Einaudi. Turin.

Paoli, L. and Fijnaut, C., 2006. Organised crime and its control policies. European Journal of Crime Criminal Law and Criminal Justice, 14(3), 307-327.

Paoli, L. and Vander Beken, T., 2014. Organized crime. In Paoli, L. (ed.), The Oxford Handbook of Organized Crime, pp. 13-31. Oxford University Press. Oxford.

Project OCP, 2015. From illegal markets to legitimate businesses: the portfolio of organised crime in Europe. http://www.transcrime.it/wp-content/uploads/2015/03/OCP-Full-Report.pdf (accessed 31 December 2017).

Rawlinson, P., 2000. Mafia, methodology, and 'alien' culture. In King, R. and Wincup, E. (eds), Doing Research on Crime and Justice, pp. 351-362. Oxford University Press. New York.

Sciarrone, R. and Storti, L., 2014. The territorial expansion of mafia-type organized crime: the case of the Italian mafia in Germany. Crime, Law and Social Change, 61(1), 37-60.

UN, 2000. United Nations Convention against Transnational Organized Crime and the Protocols Thereto. UNODC. Vienna. https://www.unodc.org/documents/middleeastandnorthafrica/organised-crime/UNITED _NATIONS_CONVENTION_AGAINST_TRANSNATIONAL_ORGANIZED_CRIME_AND_THE_PR OTOCOLS_THERETO.pdf (accessed 31 December 2017).

Varese, F., 2001. The Russian Mafia: Private Protection in a New Market Economy. Oxford University Press. Oxford.

Varese, F., 2010. General introduction, 'What is organised crime?'. In Varese, F. (ed.), Organized Crime: Critical Concepts in Criminology, Vol. I, pp.11-33. London. Routledge. http://federicovarese.com/sites/default/files/ What_is_Organized_Crime-Introduction.pdf (accessed 3 March 2018).

Walliman, N., 2011. Research Methods: The Basics. Routledge. Abingdon.

\section{Interview}

Interview 1: SM, Interview with former member of Gionta Clan, Naples Tribunal, 22 September 1997. 


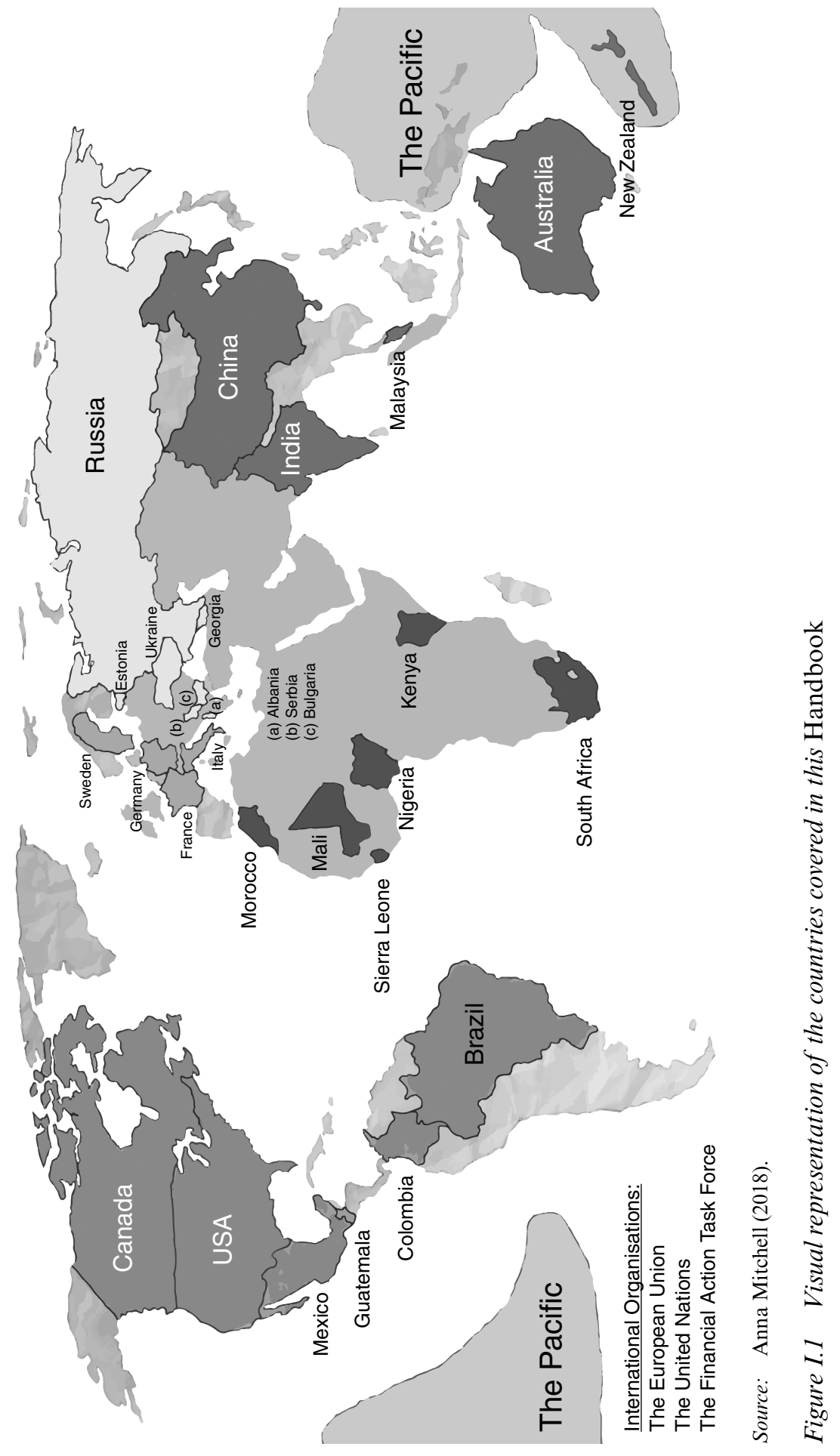

